\title{
PENGAMANAN PILAR BANGSA DAN MASA DEPAN NEGARA KESATUAN REPUBLIK INDONESIA
}

\author{
M. Aqil Irham \\ IAIN Raden Intan Lampung \\ aqilirham@yahoo.com
}

\begin{abstract}
Abstrak
Sejak reformasi bergulir di Indonesia, terdapat dua kecenderungan yang berkembang dalam masyarakat. Pada satu sisi, masyarakat berharap bahwa penegakan demokrasi di segala bidang dapat ditegakkan, tetapi di sisi lain, sebagai akibat dari euphoria politik, masyarakat cenderung keluar dari koridor ketatanegaraan dan mengabaikan nilai-nilai kemanusiaan dan karakter masyarakat yang berakal dan beradab. Kecenderungan yang kedua ini muncul karena pilar-pilar bangsa- Pancasila, UUD 1945, Bhinneka Tunggal Ika, dan Negara Kesatuan Republik Indonesia- telah dinafikan bahkan dilupakan. Tulisan ini mengkaji upaya penegakan empat pilar bangsa sebagai suatu strategi dalam menjaga keutuhan NKRI. Dalam upaya tersebut, langkah utama yang harus dilakukan adalah merevitalisasi secara epistemologis Pancasila lewat kajian-kajian ilmiah di dunia pendidikan. Selain dari itu, konsepsi dan makna dari empat pilar kebangsaan tersebut harus juga diperkenalkan dan dikembangkan dalam wacana publik. Melalui langkah-langkah ini, kristalisasi nilainilai yang terkandung dalam pilar-pilar kebangsaan tersebut dapat diwujudkan tanpa melalui proses pemaksaan dan penggunaan hegemoni kekuasaan.
\end{abstract}

\section{Abstract}

PRESERVING NATIONAL PILARS AND THE FUTURE OF THE UNITARY STATE OF REPUBLIC OF INDONESIA. Starting from the reformation era in Indonesia, there are two trends developing in the society. On the one hand, people are expecting the enforcement of democracy in all spheres, but on the other hand, as a result of political euphoria, people also tend to get out of the corridors of state regulations and to ignore human values and characters of a rational and civilized society. It is assumed that the second trend emerges as the four nation pillars- i.e the Pancasila, the 
Constitution of 1945, the national motto of Bhinneka Tunggal Ika, and the Unity of the Republic of Indonesia- have been denied even forgotten. This paper examines the enforcement efforts of the four pillars of the nation as a strategy to maintain the integrity of the Republic of Indonesia. In these efforts, the main steps that must be done is to revitalize epistemologically the Pancasila through academic inquiries. Aside from that, the conception and the meaning of the four pillars should also be introduced and developed in the public spheres. Through these measures, the crystallization of the values contained in the pillars of nationality can be realized without going through the process of coercion and the use of state hegemony.

Kata Kunci : Pilar Bangsa; Masa Depan Indonesia

\section{A. Pendahuluan}

Fakta sosial yang tak terbantahkan dimana Indonesia merupakan bangsa plural yang terdiri dari berbagai macam suku, agama, bahasa, ras juga budaya. Disatu sisi, keragaman tersebut jika dapat bersinergi maka menjadi keunikan tersendiri yang tidak dimiliki oleh bangsa lain, tetapi disisi lain, masih ada riakriak dan keinginan segelintir kelompok tertentu - terutama yang berpandangan bahwa Islam sebagai mayoritas - agar Indonesia ditetapkan sebagai negara Islam. Gagasan ini bukanlah hal yang baru, sebab jika ditengok pada sejarah perjuangan kemerdekaan Indonesia, gagasan untuk menerapkan pemikiran ini sudah terasa sejak pertamakali bangsa ini ingin menuju gerbang kemerdekaan.

Pada awal era reformasi, nampaknya kelompok ini memperoleh momentum penting untuk segera merealisasikan pemikiran tersebut. Hal ini dapat dilihat betapa banyaknya tekanan yang muncul ketika Sidang Tahunan MPR 2002 yang menuntut penerapan syari'ah Islam ${ }^{1}$ yang dilakukan oleh beberapa organisasi keagamaan seperti Hizbut Tahrir Indonesia (HTI), Majelis Mujahidin Indonesia (MMI), Laskar Jihad dan lain-lain. ${ }^{2}$ Haedar Nashir

${ }^{1}$ Dalam salah satu bukunya, Adian Husaini memprofokasi dan menganggap bahwa perjuangan menegakkan Syari'at Islam di Indonesia "Belum Berkahir". Lihat Adian Husaini, Pancasila Bukan Untuk Menindas Hak Konstitusional Umat Islam, (Jakarta : Gema Insani Press. 2009), h. 231.

${ }^{2}$ Kajian tentang HTI dan MMI lihat antara lain Syukron Kamil, "Fenomena Gerakan Penerapan Syariat Islam: Studi atas Majlis Mujahidin Indonesia"dan Kurniawan Abdullah, "Fenomena Gerakan Politik Islam Ekstraparlementer : Studi atas Hizbut Tahrir Indonesia”, dalam Dialog: Jurnal Penelitian dan Kajian Keagamaan, 
sebagaimana dikutip Mahfud MD, menyebutkan sampai kini masih ada sekurang-kurangnya tiga gerakan resmi yang bersifat terbuka memperjuangkan formalisasi syariat Islam, bahkan menjadikan Indonesia sebagai negara Islam yaitu Hizbut Tahrir Indonesia (HTI), merupakan organisasi yang secara terbuka memperjuangkan Indonesia menjadi negara Islam, Majelis Mujahidin Indonesia (MMI) yang memperjuangkan berlakunya hukum Islam menjadi hukum nasional tanpa harus menjadikan Indonesia sebagai negara Islam, dan Komite Persiapan Pemberlakuan Syari'at Islam (KPPSI) Sulawesi Selatan memilih jalan realistis dengan memperjuangan berlakunya syariat Islam melalui berbagai Peraturan Daerah (Perda) dengan memanfaatkan peluang otonomi daerah yang dibuka secara luas. ${ }^{3}$

Hal yang sama juga banyak dilakukakan oleh kalangan aktivis (Islam) dengan memunculkan jargon "Kembali Kepada Piagam Jakarta", ${ }^{4}$ serta yang tak kalah serunya, anggota legeslatif yang berasal dari Partai Politik berbasis agama (Islam) pun (meski tidak semua) juga menyuarakan pemikiran yang sama. Meskipun pada akhirnya, segenap pemikiran tersebut secara konstitusional tidak dirumuskan. Kemudian pada tahun 2011, muncul kembali apa yang disebut dengan NII (Negara Islam Indonesia). Bahkan aksi terorisme di Indonesia akhir-akhir ini ditengarai memiliki pemikiran yang sama, sebagaimana disampaikan Presiden Susilo Bambang Yudhoyono beberapa waktu yang lalu sebelum melakukan lawatan ke negara tetangga Singapura.

Fenomena tersebut, menurut hemat penulis adalah semacam bentuk pengingkaran bahkan pengkhianatan terhadap cita-cita dan kesepakatan founding fathers yang telah bersusah payah berjuang mengorbankan jiwa dan raga hanya untuk mempertahankan kesatuan negara Indonesia yang merdeka sebagai warisan kepada anak cucu mereka.

No. 59 Th. XXVIII Juni 2005, h. 7-56.

${ }^{3}$ Mahfud MD,"Jiwa Syariat Dalam Konstitusi Kita” (Kata Pengantar), dalam Masdar Farid Mas'udi, Syarah Konstitusi UUD 1945 Dalam Perspektif Islam, (Jakarta : Alvabet. 2010), h. xvi.

${ }^{4}$ Dalam salah satu bukunya, Adian Husaini secara provokatif menganggap bahwa perjuangan menegakkan Syari'at Islam di Indonesia "Belum Berakhir". Lihat Adian Husaini, Pancasila Bukan Untuk Menindas Hak Konstitusional Umat Islam, (Jakarta : Gema Insani Press. 2009), h. 231. 
Oleh karena itu, sosialisasi empat pilar Bangsa yakni Pancasila, UUD 1945, Bhinneka Tunggal Ika, dan Negara Kesatuan Republik Indonesia (NKRI) sebagai Dasar Negara Indonesia dan Pandangan Hidup Bangsa Indonesia merupakan suatu hal yang mendesak untuk segera dilakukan secara bertanggungjawab agar tidak terjadi historical irrelevance, supaya masyarakat Indonesia disamping hidup merdeka dapat bersatu, berdaulat, merasakan keadilan dan kemakmuran sesuai yang termaktub pada pembukaan Undang-Undang Dasar 1945.

\section{B. Pancasila}

Sebagaimana diuraikan pada pengantar diatas bahwa sampai saat ini masih ada keinginan sekelompok masyarakat Indonesia untuk menjadikan agama (Islam) sebagai dasar Negara. Jika ditengok dalam lintasan sejarah perjuangan kemerdekaan Indonesia, maka terlihat bahwa pembukaan Undang-Undang Dasar 1945 baru terumuskan secara final pada tanggal 18 Agustus 1945. ${ }^{5}$ Walaupun demikian, dia bukanlah suatu naskah yang baru terjadi saat itu. Proses sejarah sampai ke tanggal 18 Agustus 1945 harus ditelusuri mulai dari tanggal 1 Juni 1945, ketika Bung Karno menyampaikan pidatonya tentang Pancasila. ${ }^{6}$ Pidato inilah yang memacu BPUPKI untuk menugaskan suatu panitia kecil yang terdiri dari Sembilan orang, ${ }^{7}$ untuk mengembangkan berbagai usulan yang masuk mengenai kemerdekaan Indonesia.

"Panitia Sembilan" mengadakan rapat pada tanggal 22

${ }^{5}$ Safroedin Bahar dkk. Peny., Risalah Sidang Badan Penyelidik Usaha-Usaha Persiapan Kemerdekaan Indonesia (BPUPKI) - Panitia Persiapan Kemerdekaan Indonesia (PPKI) : 28 Mei 1945 - 22 Agustus 1945, (Jakarta : Sekretariat Negara Republik Indonesia. 1995), h. 419.

${ }^{6}$ Pidato tersebut mengungkapkan lima prinsip, yang kemudian disebutnya dengan Pancasila yang urutannya adalah: 1. Nasionalisme Indonesia, 2. Internasionalisme atau Kemanusiaan, 3. Permusyawaratan atau Demokrasi, 4. Keadilan Sosial, 5. Kepercayaan terhadap Tuhan. Lihat Onghokham dan Andi Achdian, "Pancasila: Dari Kontrak Sosial Menjadi Ideologi Negara" dalam Irfan Nasution dan Roni Agustinus (Peny.), Restorasi Pancasila; Mendamaikan Politik Identitas dan Modernitas, (Jakarta : FISIP UI. 2006), h. 100.

${ }^{7}$ Mereka adalah Ir. Soekarno, Muhammad Hatta, Mr. A. Maramis (tokoh Kristen), Abi Kusno Tjokrosoejoso, Abdul Kahar Muzakar, H. Agus Salim, Achmad Subarjo, K.H. Wahid Hasyim, dan Mr. Muhammad Yamin. 
Juni 1945 di gedung Jawa Hookokai. Rapat tersebut menghasilkan "Rancangan Dasar Negara" atau Mukadimah yang dikenal juga sebagai "Piagam Jakarta (Jakarta Charter) ${ }^{8}$ yang ditandatangani pada hari itu juga di rumah Ir. Soekarno. ${ }^{9}$ Naskah pembukaan (preambule) yang kemudian dianggap sebagai suatu kesepakatan yang tinggi di antara pendukung paham nasionalis dan pendukung Islam. ${ }^{10}$ Dalam Piagam Jakarta itu disebutkan bahwa Indonesia berdasarkan pada : (1) Ketuhanan, dengan kewajiban menjalan syariat Islam bagi pemeluk-pemeluknya; (2) Kemanusiaan yang Adil dan Beradab; (3) Persatuan Indonesia; (4) Kerakyatan yang dipimpin oleh hikmah kebijaksanaan dalam permusyawaratan perwakilan; (5) Keadilan sosial bagi seluruh rakyat Indonesia. Dokumen ini ditandatangani oleh 9 (Sembilan) orang pemimpin Indonesia yang paling terkemuka, delapan diantaranya beragama Islam dan seorang beragama Kristen, yaitu A.A. Maramis. ${ }^{11}$

${ }^{8}$ Sejumlah ahli hukum dan intelektual waktu itu memberikan penghargaan yang tinggi terhadap Piagam Jakarta ini. Prof. Dr. Soepomo menyatakan Piagam Jakarta merupakan "Perjanjian Luhur", Dr. Sukiman menyebutnya "Gentlemen Agreement", dan Mr. Muhammad Yamin menamakannya "Jakarta Charter", sedangkan Prof. Dr. Notonagoro menjulukinya "Suatu Perjanjian moril yang sangat luhur". Lihat Alwi Shahab, "Piagam Jakarta : Kisah Tujuh Kata Sakral”, dalam Kurniawan Zein dan Sarifuddin HA (ed.), Syariat Islam Yes Syariat Islam No; Dilema Piagam Jakarta dalam Amandemen UUD 1945 (Jakarta : Paramadina. 2001), h. 5.

${ }^{9}$ Gumilar Rusliwa Somantri, "Pancasila dalam Perubahan Sosial-Politik Indonesia Modern”, dalam Irfan Nasution dan Roni Agustinus (Peny.), Restorasi Pancasila....., h. 5.

${ }^{10}$ John A. Titaley, Nilai-Nilai Dasar yang Terkandung Dalam Pembukaan UndangUndang Dasar 1945, (Salatiga : Fakultas Teologi Universitas Kristen Satya Wacana, 1999), h. 5.

${ }^{11}$ Nurcholish Madjid, Islam Agama Kemanusiaan; Membangun Tradisi dan Visi Baru Islam Indonesia, (Jakarta : Paramadina, 1995), h. 4. Menurut Nurcholis, Piagam Jakarta ini sebenarnya dimaksudkan sebagai teks Deklarasi kemerdekaan bangsa tepat pada waktunya masih harus dirumuskan, dan ia dimasukkan mukaddimah dari konstitusi Indonesia yang diusulkan. Namun, tatkala Soekarno dan M. Hatta memproklamirkan kemerdekaan pada tanggal 17 Agustus 1945, mereka tidak menggunakan piagam ini. Sebaliknya mereka merumuskan sebuah dokumen baru, kemudian dikenal sebagai Teks Proklamasi, sebuah dokumen yang sangat ringkas yang di dalamnya tidak disebutkan secara rinci apa yang akan dijadikan nature dari negara Indonesia merdeka, dan di dalamnya tidak pula disebutkan sesuatu yang menyangkut agama Islam atau agama lainnya. 
Keesokan harinya, tanggal 18 Agustus 1945, tatkala berlangsung rapat PPKI untuk merumuskan konstitusi, ada informasi yang menyatakan bahwa orang-orang Kristen yang berasal dari Sulawesi Utara, tanah kelahiran A.A. Maramis, secara serius menolak satu ungkapan dalam piagam tersebut yang menyatakan "Ketuhanan dengan kewajiban menjalankan syariat Islam bagi pemeluk-pemeluknya”. Muhamad Hatta, yang memimpin rapat itu, setelah berkonsultasi dengan Teuku Muhammad Hassan dan Kasman Singodimedjo, dua pemimpin Islam terkemuka, menghapus ungkapan tujuh kata dari Piagam Jakarta yang menjadi keberatan dimaksud. Sebagai gantinya, atas usul Ki. Bagus Hadikusumo, ditambahkan sebuah ungkapan baru dalam sila Ketuhanan itu, sehingga berbunyi Ketuhanan Yang Maha Esa. ${ }^{12}$

Apa yang menyebabkan terjadinya perubahan tersebut? Salah satu versi yang paling populer adalah berasal dari Hatta yaitu pada tanggal 17 Agustus sore, Muhammad Hatta menerima telepon penting dari Nishijama (Pembantu Admiral Maeda) yang menanyakan, dapatkan ia menerima datangnya utusan dari daerah Kaigun (Angkatan Laut) Indonesia Bagian Timur. Ternyata tamu tersebut membawa pesan bahwa rakyat Indonesia disana, terutama yang beragama Katholik dan Kristen, sangat keberatan terhadap rumusan "tujuh kata” yang ada pada sila pertama Pancasila. Mereka mengakui bahwa kalimat itu memang tidak mengikat mereka, tetapi persoalannya, tercantumnya ketetapan seperti itu dalam Undang-Undang Dasar berarti mengadakan diskriminasi terhadap mereka golongan minoritas. Maka, jika "tujuh kata" itu tidak dihapus, mereka lebih suka berdiri sendiri diluar Negara Republik Indonesia. ${ }^{13}$

Akan tetapi dalam versi lain, didapatkan bahwa orang yang datang kerumah Hatta tersebut bukanlah anggota Angkatan Laut Jepang, tetapi tiga orang mahasiswa yaitu Piet Mamahit, Moeljo, dan Imam Slamet yang berpakaian seragam Angkatan Laut, sehingga

${ }^{12}$ Ibid. h. 5.

${ }^{13}$ Sampai tahun 1984 masih misterius dan tidak ada satu bukupun di Indonesia yang menjelaskan siapa gerangan yang member ultimatum (melalui Jepang) itu. Baru setelah Cornell University di Amerika Serikat menerbitkan sebuah buku tentang Indonesia disebutkan bahwa tokoh itu ialah Dr. Sam Ratulangi. Lihat Shahab,"Piagam Jakarta ....., h. 5. 
orang mengiranya orang Jepang. Wajah Imam Slamet seperti orang Cina, badannya pendek, jadi mirip seperti orang Jepang. (Lama kemudian ketika Nishijama berkunjung ke Jakarta, ia menerangkan bahwa tidak ada orang Jepang, juga dia sendiri yang datang kepada Hatta untuk membicarakan soal itu. Sejak Proklamasi tidak ada lagi orang Jepang pergi bertamu ke rumah Hatta). ${ }^{14}$

Meskipun agak berbeda versi dengan penjelasan Hatta, tetapi intinya sama, yakni tuntutan pihak Kristen dan lainnya yang merasa keberatan dengan anak kalimat "dengan kewajiban menjalankan syariat Islam bagi pemeluk-pemeluknya” sebagaimana yang tercantum dalam Piagam Jakarta. Sehingga pada tanggal 18 Agustus 1945 terjadilah perubahan-perubahan sebagaimana yang dikemukakan diatas.

Setelah Soekarno membuka rapat, Hatta diberikan waktu untuk menyampaikan perubahan-perubahan yang telah ada. Perubahan yang langsung menyangkut hubungan negara-agama, antara lain : Pertama, penghapusan "tujuh kata". Perubahan ini merupakan wujud toleransi, semata-mata demi keselamatan negara Indonesia yang bersatu. Kedua, pasal 6 ayat 1 menjadi "Presiden ialah orang Indonesia asli", berarti kata "yang beragama Islam" dicoret. Ketiga, pasal 29 ayat 1 disesuaikan dengan pembukaan UUD 1945 (penghapusan tujuh kata). Keempat, atas usul I Gusti Ketut Puja dari Bali, alenia 3 "Atas berkat rahmat Allah diganti dengan "Atas berkat rahmat Tuhan Yang Maha Kuasa”. ${ }^{15}$

${ }^{14}$ O.E. Engelan dkk., Lahirnya Satu Bangsa dan Negara, (Jakarta : Universitas Indonesia Press, 1997), h. 89-90.

${ }^{15}$ Bahar, Risalah Sidang...., h. 419. Bandingkan dengan Endang Syaifuddin Anshari, Piagam Jakarta 22 Juni 1945 ; Sebuah Konsensus Tentang Dasar Negara Republik Indonesia, (1945-1949), (Bandung: Gema Insani Press, 2001), h. 47. Namun dalam disertasi Adnan Buyung Nasution disebutkan bahwa tidak betul kalau pencoretan tujuh kata itu dipandang semata-mata sebagai konsesi bagi orang-orang Kristen dan bukan Muslim lain. Pada kenyataannya, sebaliknya, tujuh kata itu semula dikonsesikan kepada "kelompok Islam" dalam BPUPKI supaya mereka mau menerima agar Indonesia tidak menjadi Negara Islam. Hal itu tidak dikehendaki oleh "kelompok nasionalis" yang kebanyakan juga terdiri atas orang Islam. Bagi mereka penolakan saudara-saudara Kristen Indonesia Timur menjadi alasan yang dimanfaatkan untuk mencoret tujuh kata yang tidak pernah betul-betul mereka sukai. Dalam pemungutan suara di Konstituante hasil pemilihan umum 1955, suara yang menolak sebanyak 265 suara sedangkan yang mendukung dimasukkannya 
MenurutYudi Latif, dapat dikatakan bahwa 1 Juni merupakan hari kelahiran Pancasila. Pada hari itulah, lima prinsip dasar negara dikemukakan dengan diberi nama Panca Sila, dan sejak itu jumlahnya tidak pernah berubah. Meski demikian, untuk diterima sebagai dasar negara, Pancasila itu perlu persetujuan kolektifmelalui perumusan Piagam Jakarta (22 Juni), dan akhirnya mengalami perumusan final melalui proses pengesahan konstitusional pada 18 Agustus. Oleh karena itu, rumusan Pancasila sebagai dasar negara yang secara konstitusional mengikat kehidupan kebangsaan dan kenegaraan bukanlah rumusan Pancasila versi 1 Juni atau 22 Juni, melainkan versi 18 Agustus $1945 .^{16}$

Jadi dengan demikian, Pancasila merupakan dasar negara ${ }^{17}$ sekaligus merupakan kontrak sosial bagi masyarakat Indonesia. Penggunaan istilah Pancasila sebagai kontrak sosial dapat dilacak dalam pidato Soekarno yang mengatakan :

"Kita bersama-sama mencari persatuan philosophische grondslag, mencari satu "Weltanschaung" yang kita semua setuju. Saya katakan lagi setuju! Yang saudara Yamin setujui, yang Ki Bagoes setujui, yang Ki Hajar setujui, yang sdr. Sanusi setujui, yang sdr. Abukoesno setujui, yang sdr. Lim Koen Hian setujui, pendeknya kita mencari semua satu modus. Tuan Yamin, ini bukan compromise, tetapi kita bersama-sama mencari satu hal yang kita bersama-sama setujui."

Kalimat "kita bersama-sama mencari satu hal yang kita bersama-sama setujui” menurut Onghokham dan Andi Achdian, dalam bahasa politik modern tidak lain adalah kontrak sosial. ${ }^{18}$

kembali tujuh kata dalam Pancasila sebanyak 201 suara. Lihat Adnan Buyung Nasution, The Aspiration for Constitutional Government in Indonesia: A Socio-Legal Study of the Indonesian Konstituante 1956-1959, (Jakarta: Pustaka Sinar Harapan, 1992), h. 397.

${ }^{16}$ Yudi Latif, Negara Paripurna; Historisitas, Rasionalitas dan Aktualitas Pancasila (Jakarta : Gramedia Pustaka Utama, 2011), h. 40.

${ }^{17}$ Penggunaan istilah dasar negara (Philosophische Grondslag) bagi Pancasila tentu sangat beralasan, sebab "Pancasila mengutip Abdurrahman Wahid [saat menjabat sebagai Presiden], adalah memuat deretan prinsip-prinsip aturan hidup bernegara...., sedangkan falsafah itu tak lebih dari sekedar deretan prinsip-prinsip ilmu pengetahuan." Lihat Kompas, Presiden: "Pertahankan Pancasila Habis-Habisan", 2 Juni 2000.

${ }^{18}$ Onghokham dan Andi Achdian, "Pancasila : Dari Kontrak Sosial Menjadi Ideologi Negara”, dalam Irfan Nasution dan Rony Agustinus (Peny.), Restorasi Pancasila; Mendamaikan Politik Identitas dan Modernitas, (Depok : FISIP UI, 2006), h. 94. 
Dengan demikian dipahami bahwa, Pancasila lebih tepat disebut sebagai dasar negara dan sebagai kontrak sosial ketimbang falsafah ataupun ideologi negara.

Secara moral dan politik - kata Komaruddin Hidayat kita pantas sekali menghargai dan meneruskan visi para pendiri bangsa yang sejak awal telah meletakkan dasar negara (Pancasila) berdasarkan semangat humanis religious. Komitmen mereka untuk mejunjung tinggi nilai-nilai kegamaan dan kemanusiaan untuk dikembangkan dalam lokus keIndonesiaan adalah bukti nyata bahwa sejak awal sesungguhnya bangsa ini sudah melangkah dan membuat antisipasi, akan hadirnya masyarakat global yang pluralistik diikat oleh prinsip-prinsip kemanusiaan dan ketuhanan. ${ }^{19}$

Walaupun pada awalnya terjadi perdebatan hebat tentang landasan dasar yang akan dijadikan pijakan bagi Republik Indonesia. Nasionalis muslim atau setidaknya yang secara Islami mengilhami orang-orang nasionalis, menginginkan Indonesia yang merdeka berlandaskan Islam, dan itu berarti mengimplikasikan berdirinya negara Islam Indonesia (Islamic State of Indonesia). Akan tetapi nasionalis sekuler, yang kebanyakan dari mereka adalah penganut Islam sendiri dan non Muslim, menolak gagasan tersebut, sehubungan dengan kenyataan bahwa, ada juga non-muslim yang turut berjuang melawan kolonialis. Nasionalis sekuler itu juga mengingatkan bahwa menjadikan Indonesia sebagai sebuah negara Islam sama saja dengan merendahkan, secara tidak adil penganut agama lain kedalam warga negara kelas dua. Kelompok ini menghendaki yang dijadikan dasar negara Indonesia adalah Pancasila. Setelah melalui diskusi dan perdebatan yang panjang, maka Pancasila-lah yang diterima oleh semua pihak ketika itu untuk dijadikan sebagai dasar negara Indonesia.

Pilihan founding fathers tersebut tegas Nurcholish Madjid, bisa dikatakan cukup tepat, untuk tidak mengatakan mutlak adanya. Apa yang terjadi seandainya negara ini dimerdekakan dengan bentuk negara agama atau negara sekuler. Kemungkinan perpecahan, ancaman dis-integrasi bangsa telah bermunculan sejak awal republik ini berdiri. Pilihan untuk menjadi negara non agama

\footnotetext{
${ }^{19}$ Komaruddin Hidayat, Wahyu di Langit, Wahyu di Bumi; Doktrin dan Peradaban Islam di Panggung Sejarah, (Paramadina : Jakarta, 2003), h. 160.
} 
ketika itu memang memberikan dasar-dasar yang kuat bagi ini untuk bersikap toleran, menghargai kepelbagaian dan menjunjung tinggi perbedaan. Sedangkan pilihan untuk tidak menjadi negara sekuler, jelas membuktikan bahwa negeri ini rakyatnya bisa di bilang religious society, masyarakat yang ber-Tuhan, bukan anti Tuhan. ${ }^{20}$ Dengan mendudukkan Pancasila sebagai common value bagi umat beragama, maka segala macam bentuk egoisme dan perasaan ada anak emas atau ada anak tiri dan lain sebgainya dapat disingkirkan. Penulis berpandangan, saat ini makna Pancasila harus dikembalikan kepada pengertian semula yaitu sebagai dasar negara dan kontrak sosial bagi seluruh masyarakat Indonesia.

\section{UUD 1945}

Secara historis dilihat bahwa sejak Proklamasi Kemerdekaan Indonesia tanggal 17 Agustus 1945 sampai saat ini, di Indonesia telah diterapkan tiga konstitusi , yaitu UUD 1945, Konstitusi Republik Indonesia Serikat, dan Undang-Undang Dasar Sementara 1950. Konstitusi Republik Indonesia Serikat (Konstitusi RIS) berlaku di Indonesia dari tanggal 27 Desember 1949 sampai tanggal 18 Agustus 1950. Undang-Undang Dasar Sementara 1950 berlaku dari tanggal 18 Agustus 1950 sampai tanggal 5 Juli 1959. Sedangkan UndangUndang Dasar 1945 berlaku di seluruh Indonesia dalam dua kurun waktu, yaitu antara tahun 1945 sampai Desember 1949, dan sejak 5 Juli 1959 sampai sekarang.

Peralihan dari UUD 1945 yang ditetapkan pada tanggal 18 Agustus 1945 ke Konstitusi RIS pada tanggal 27 Desember 1949 disebabkan tekanan atau pengaruh pihak luar. Setelah Indonesia dinyatakan merdeka, pasukan serikat datang ke Indonesia guna menegakkan kembali kekuasaan pemerintah Hindia Belanda. ${ }^{21}$ Pertempuran-pertempuran terjadi antara pasukan serikat dengan pihak Indonesia. Disamping itu dilakukan langkah-langkah diplomatik melalui perundingan-perundingan guna mencari penyelesaian pertikaian. Pada tanggal 23 Agustus hingga 2

\footnotetext{
${ }^{20}$ Nurcholish Madjid, Islam Agama Kemanusiaan; Membangun Tradisi dan Visi Baru Islam Indonesia, (Jakarta : Paramadina, 1995), h. 3.

${ }^{21}$ Marwati Djoenoed Posponegoro dan Nugroho Notosusanto, Sejarah Nasional Indonesia, (Jakarta : Balai Pustaka, 1990), h. 122. Lihat juga M.C. Ricklefs, Sejarah Indonesia Modern (Yogyakarta : Gadjah Mada University Press, 2007).
} 
November 1949 dilaksanakan Konferensi Meja Bundar (KMB) di Den Haag. KMB itu menghasilkan berdirinya Republik Indonesia Serikat dan Konstitusi RIS. ${ }^{22}$

Terbentuknya negara Republik Indonesia Serikat, menimbulkan rasa tidak puas bangsa Indonesia. Pada tanggal 17 Agustus 1950 RIS dibubarkan dan dibentuk kembali negara kesatuan Republik Indonesia. Sejak tanggal tersebut, berlaku Undang-Undang Dasar Sementara (UUDS) 1950. Konstituante hasil pemilihan umum tahun 1955 yang bertugas menetapkan Undangundan Dasar yang definitif gagal menjalankan tugasnya. Hal ini mengakibatkan dilakukannya Dekrit Presiden tanggal 5 Juni 1959, ${ }^{23}$ yang antara lain menetapkan UUD 1945 berlaku kembali di seluruh wilayah negara Republik Indonesia.

Dalam setiap negara sudah pasti memiliki sebuah peraturan yang mengatur kehidupan bernegara, yang di Indonesia disebut dengan Undang-Undang Dasar 1945 yang telah dirumuskan para founding fathers, dalam rangka memberikan rambu-rambu bagi pelaksanaan tata kehidupan berbangsa dan bernegara. Secara yuridis, fakta eksistensi UUD tidak dapat dapat dinafikan, karena telah melalui perumusan dan kesepakatan secara demokatis. Adapun jika terdapat kekurangan-kekurangan, maka prosesnya pun harus melalui amandemen, sebagaimana yang pernah terjadi sejak era reformasi. Bukan melalui cara-cara kekerasan apalagi pemaksaan.

Indonesia di era reformasi pernah melakukan empat kali ${ }^{24}$ amandemen (perubahan) terhadap UUD $1945^{25}$, yang tujuannya

${ }^{22}$ Ibid., h. 171.

${ }^{23}$ Tentang perjalanan munculnya Dekrit Presiden Sukarno, lihat antara lain Endang Saifuddin Anshari, Piagam Jakarta 22 Juni 1945; Sebuah Konsensus Nasional Tentang Dasar Negara Republik Indonesia, (1945-1959) (Jakarta : Gema Insani Press, 2001).

${ }^{24}$ Amandemen pertama telah disahkan pada tanggal 19 Oktober 1999, amandemen kedua tanggal 18 Agustus 2000, amandemen ketiga tanggal 10 November 2001, sedangkan amandemen keempat pada tanggal 10 Agustus 2002.

${ }^{25}$ Pada kurun tahun 1999-2002, UUD 1945 telah mengalami 4 kali amandemen, yang mengubah susunan lembaga-lembaga dalam sistem ketatanegaraan Republik Indonesia. Sebelum dilakukan amandemen, UUD 1945 terdiri atas Pembukaan, Batang Tubuh (16 bab, 37 pasal, dan 65 ayat, 4 pasal aturan peralihan, dan 2 ayat aturan tambahan), serta penjelasan. Saat ini UUD 1945 
adalah melakukan revisi atau perumusan ulang terhadap beberapa penjelasan atau uraian pada batang tubuh UUD 1945 yang dianggap secara umum tidak sebangun dengan cita-cita demokrasi yang sangat dijunjung tinggi oleh pemerintah Indonesia. Jika demikian, maka merupakan suatu tuntutan untuk menyempurnakan sebuah konstitusi yang merupakan produk manusia, atau dengan kata lain UUD bukanlah suatu yang untouchble. Akan tetapi pelaksanaan amandemen terhadap UUD 1945 harus dilaksanakan secara arif, bijaksana karena berdasarkan nurani, bukan berdasarkan persoalan mayoritas-minoritas. Karena itu, selagi UUD tersebut masih berlaku, maka sudah menjadi kewajiban bagi rakyat Indonesia untuk melaksanakan, menjalankan dan juga mengamankannya dari tindak laku oknum-oknum yang ingin merusak persatuan dan kesatuan rakyat Indonesia dengan dalih apapun.

Menurut penulis, umat beragama di Indonesia sangatlah beruntung karena memiliki pandang hidup (way of life) yang sangat representatif dan aspiratif yakni Pancasila sebagai dasar negara, juga landasan Konstitusionil yakni Undang-Undang Dasar (UUD) 1945, dimana dalam pasal 29 ayat 1 dinyatakan "Negara berdasar atas Ketuhanan Yang Maha Esa. Sedangkan dalam ayat 2 ditegaskan Negara menjamin kemerdekaan tiap-tiap penduduk untuk memeluk agamanya masing-masing dan untuk beribadat menurut agama dan kepercayaannya itu".

\section{Bhinneka Tunggal Ika}

Semboyan Bhinneka Tunggal Ika sudah sangat populer di telinga setiap insan Indonesia, karena sudah menjadi Motto bagi bangsa yang plural seperti Indonesia. Motto ini secara sederhana dapat diartikan "bersatu dalam perbedaan dan berbeda dalam persatuan”, maksudnya bahwa bangsa Indonesia yang terdiri dari berbagai macam agama, suku, ras, bahasa dan lain sebagainya, tidak menyebabkan untuk terjadi pertentangan apalagi peperangan. Pun sebaliknya meskipun terdapat perbedaan dan keanekaragaman, bukanlah menjadi suatu halangan bagi rakyat Indonesia untuk

memiliki 20 bab, 73 pasal, 194 ayat, 3 pasal aturan peralihan, dan 2 pasal aturan tambahan. Lihat JF. Tualaka (Peny.), Buku Pintar Politik; Sejarah, Pemerintahan, dan Ketatanegaraan, (Yogyakarta : Great Publisher, 2009), h. 59-60. 
bersatu dalam rangka mempertahankan wilayah negara kesatuan republik Indonesia.

Menurut penulis, motto ini sangat hebat karena telah dilahirkan dari pikiran-pikiran yang brilian dari para pendiri bangsa. Masykuri Abdillah menegaskan, founding fathers memformulasikan motto Bhinneka Tunggal Ika adalah dalam rangka memperhitungkan dan mempertimbangkan situasi pluralitas dengan segala macam bentuknya. ${ }^{26}$

Penerapan konsep Bhinneka Tunggal Ika merupakan implementasi dari sila ketiga yakni Persatuan Indonesia. Karenanya harus benar-benar dilaksanakan secara bertanggung jawab, sehingga akan mampu memberikan kesadaran bahwasanya keanekargaman (pluralistik) harus direspon secara aktif, kreatif, dan positif dan tidak seharusnya menjadikan rakyat Indonesia menjadi berpecah belah, karena keanekaragaman merupakan kehendak Tuhan (sunnatullah). Menurut Hardono Hadi, "Kalau Bhinneka Tunggal Ika" menjadi semboyan perjuangan bangsa Indonesia, maka hal itu sekaligus menjadi batu penguji manusia Indonesia, sejauh mana dia menghayati sila pertama, kedua, bahkan ketiga". ${ }^{27}$ Pada sisi lain K.H. Mustofa Bisri dalam acara "Indonesia Hebat" di TV One yang ditayangkan pada tanggal 2 Maret 2012 mengatakan, bahwa "kebhinnekaan atau kemajemukan, tidaklah menghalangi kita untuk bersatu tetapi seharusnya dengan kemajemukan kita bersama-sama dan bersatu untuk membangun bangsa Indonesia”.

Dengan demikian, maka konsep Bhinneka Tunggal Ika pun layaknya menjadi kesadaran bersama seluruh elemen bangsa ini, agar supaya tidak terjadi tindakan diskriminasi hanya karena adanya perbedaan suku, ras, bahasa, budaya, dan agama. Bahkan sebaliknya, konsep ini pun mengisyaratkan untuk bersatu meskipun terdapat berbagai perbedaan.

${ }^{26}$ Masykuri Abdillah, “Toleransi Beragama dalam Masyarakat Demokrasi dan Multikultural" dalam W.A.L. Stokhof dan Murni Djamal (redaktur), Konflik Komunal di Indonesia Saat ini, (Jakarta - Leiden : INIS dan Pusat Bahasa UIN Syarif Hidayatullah, 2003), h. 177.

${ }^{27} \mathrm{P}$. Hardono Hadi, Hakikat dan Muatan Filsafat Pancasila, (Yogyakarta: Kanisius, 1994), h. 99. Lihat juga Soejadi, Pancasila Sebagai Sumber Tertib Hukum Indonesia (Yogyakarta : Lukman Offset, 1999). 


\section{E. Negara Kesatuan Republik Indonesia (NKRI)}

Tentang Negara Kesatuan Republik Indonesia termaktub di dalam Undang-Undang Dasar 1945 pada Bab I Pasal 1 yang berbunyi "Negara Indonesia ialah Negara Kesatuanyangberbentuk Republik". ${ }^{8}$ Dalam konsep dan teori modern saat ini tentang negara ditemukan dua bentuk yaitu negara kesatuan (unitarisme) dan negara serikat (federasi). Melihat aspek historis dan fakta yang ada, maka Indonesia menetapkan diri sebagai negara kesatuan yaitu bentuk suatu negara yang merdeka dan berdaulat, dengan satu pemerintahan pusat yang berkuasa dan mengatur seluruh daerah. Dan pelaksanaannya (saat ini) dengan sistem desentralisasi yakni kepala daerah (sebagai pemerintah daerah) diberikan kesempatan dan kekuasaan untuk mengurus "rumah tangganya" sendiri dan dikenal dengan sistem otonomi daerah. ${ }^{29}$

Wilayah Indonesia adalah dari sabang sampai merauke yang memiliki ribuan pulau dari lautan yang sangat kaya dengan berbagaimacam flora dan faunanya. Disatu sisi, luasnya wilayah ini merupakan suatu yang patut disyukuri sebab akan banyak sekali hasil kekayaan yang berasal dari lautan maupun hutan yang dapat dimanfaatkan untuk kesejahteraan rakyat Indonesia. ${ }^{30} \mathrm{Akan}$ tetapi, disisi lain mengawal sebuah negara yang luas wilayahnya terbentang bukanlah perkara yang mudah. Jika rakyat Indonesia tidak memiliki kesadaran yang utuh akan pentingnya persatuan, maka sangat mungkin terjadi rongrongan dari berbagai daerah

${ }^{28}$ Dalam salah satu bukunya Masdar Farid Mas'udi mengatakan bahwa kata Republik beasal dari rechs (hukum atau kekuasaan) dan publica (rakyat). Artinya Negara Indonesia adalah negara dengan prinsip kekuasaan tertinggi ada di tangan rakyat. Konsep Indonesia sebagai negara Republik ini, juga acapkali menjadi sasaran prasangka dari segelintir orang yang kurang informasi. Dipersangkakan bahwa konsep "negara Republik" merupakan tandingan atau bahkan perlawanan terhadap otoritas Tuhan. Padahal tudingan tersebut tidak benar dan salah alamat. Untuk lebih jelas lihat Masdar Farid Mas'udi, Syarah Konstitusi UUD 1945 Dalam Perspektif Islam, (Jakarta : Alvabet, 2010), h. 50-51.

${ }^{29}$ Abdul Rozak, dkk (ed.), Pendidikan Kewargaan; Demokrasi, Hak Asasi Manusia dan Masyarakat Madani, (Jakarta : Tim ICCE UIN Jakarta, 2003), h. 57.

${ }^{30}$ Menurut Yudi Latif, hanya negara Indonesialah yang karena keluasan wilayahnya memiliki tiga bagian waktu yaitu Bagian Barat, Tengah dan Timur. Lihat Yudi Latif, Negara Paripurna; Historisitas, Rasionalitas dan Aktualitas Pancasila, (Jakarta : Gramedia Pustaka Utama, 2011). 
yang menginginkan ide untuk merdeka seperti yang pernah terjadi di Aceh, Papua, Ambon. Oleh karenanya pengamanan wilayah negara Indonesia bukan hanya menjadi tanggung jawab pemerintah dan aparat keamanan saja, akan tetapi menjadi tanggung seluruh masyarakat Indonesia.

\section{F. Fenomena di Era Reformasi}

Sejak gerakan reformasi digulirkan, nampaknya terjadi kecenderungan untuk menafikan peranan pilar bangsa dalam kehidupan berbangsa dan bernegara. Pada sementara individu atau komunitas masyarakat terdapat apresiasi yang kurang pas terhadap keempat pilar tersebut, bahkan ada semacam sinisme. Hal ini dapat dipahami karena telah terjadi kejenuhan pada masyarakat Indonesia terhadap tekanan yang dilakukan oleh Orde Baru.

Ketika Orde Baru runtuh, gelombang euporia dari reformasi, muncul trauma besar dalam memori kolektif masyarakat Indonesia akibat perlakukan yang berlebihan terhadap Pancasila pada zaman sebelumnya. Dalam mind set masyarakat; membicarakan Pancasila, UUD 1945, Bhinneka Tunggal Ika, dan Negara Kesatuan Republik Indonesia adalah identik dengan Orde Baru dan mereka sangat muak dengan bau dan aroma Orde tersebut. Bahkan dianggap sebagai antek Orde Baru. Akibatnya saat ini banyak orang yang tidak mengerti lagi tentang Pancasila. Sebagai contoh, beberapa waktu yang lalu, salah satu stasiun TV Swasta mewawancarai kalangan remaja tingkat SLTA dengan menanyakan Pancasila berikut isinya. Dari 10 orang yang ditanya; yang menjawab secara benar hanya 4 orang, sisanya menjawab secara tidak berurutan bahkan ada yang tidak lengkap. Potret ini, tentunya sangat memprihatinkan, sebab bagaimana mungkin mereka bisa memahami Pancasila secara baik dan benar kalau urutan isi Pancasila mereka tidak hapal. Walaupun tidak ada jaminan bagi yang hapal "wiridan" Pancasila, akan menjalankan makna terkandung dalam Pancasila secara nyata dalam kehidupan bermasyarakat, berbangsa dan bernegara. Sebagaimana yang dikemukakan oleh Mahfud MD dalam acara "Todays Dialogue" di Metro TV tanggal 10 Mei 2011 bahwa "orang tidak harus hapal Pancasila, tetapi untuk bisa memahami apalagi mengimplementasikannya, maka orang harus hapal dulu Pancasila”. 
Begitu juga dengan pelaksanaan Undang-Undang Dasar 1945 yang masih sangat memperihatinkan. Penegakan hukum masih sangat lemah, nyatanya setelah 14 tahun hidup dizaman reformasi, masih sangat banyak perilaku yang bertetangan dengan nilai-nilai Pancasila, misalnya kasus korupsi yang telah menggurita disetiap instansi dan institusi yang ada; dari sipil hingga militer; dari swasta hingga pemerintah tidak terlepas dari tradisi ini. Hampir setiap waktu kita disuguhi tontontan "fantastis"; kasus illegal loging, Bank Century, Perpajakan, Markus, "istana” dalam penjara, Pelanggaran HAM, dan lain-lain yang melibatkan unsur aparat berwenang, sampai saat ini masih menjadi awan gelap yang menyelimuti bumi pertiwi.

Pemaknaan terhadap konsep Bhinneka Tunggal Ika pun mengalamidegradasisepertiberbagaimacambentrokdan kerusuhan yang merenggut jiwa, harta dan yang terpenting stabilitas yang telah dibangun selama ini seakan hilang entah kemana akibat dari tidak dimilikinya satu pegangan yang dijadikan cerminan bersama. Rasa kesukuan, kedaerahan, keagamaan, muncul kepermukaan tanpa malu-malu sehingga menambah sederet masalah yang dihadapi pemerintah di era ini, termasuk juga masalah terorisme.

Di sisi lain, mahasiswa sebagai penarik gerbong reformasi dan sebagai intellektual juga pemegang tongkat estafet kepemimpinan di masa mendatang, saat ini perilaku mereka sangat memprihatinkan. Disamping sering melakukan perbuatan tidak terpuji seperti mabuk-mabukan di kampus, terlibat pergaulan bebas di kamar kost, mahasiswa juga sering main hakim sendiri dalam menyelesaikan suatu persoalan bahkan cenderung tanpa kompromi. "Perang" antar fakultas atau antar Universitas/Perguruan Tinggi, sering kita lihat diberbagai media baik cetak maupun elektronik.

Penegakan Negara Kesatuan Republik Indonesia saat ini masih lemah, buktinya terdapat masih terdapat beberapa daerah yang ingin memisahkan diri dari NKRI atau dengan kata lain ingin "merdeka". Terlepas dari persoalan yang menyebabkan mengapa keinginan tersebut muncul, tetapi dapat dikatakan penegakan NKRI nampaknya belum menjadi kesadaran bersama. Bahkan dapat dikatakan juga sebagai pengkhianatan terhadap cita-cita founding father's untuk mempertahankan wilayah NKRI. 
Oleh karena itu diperlukan restorasi (penyegaran pemahaman) terhadap Pancasila, UUD 1945, Bhinneka Tunggal Ika, dan Negara Kesatuan Republik Indonesia dengan cara memahami esensinya lalu diimplentasikan secara konkrit dalam kehidupan empirik. Karena nilai-nilai keempat pilar bangsa tersebut sejatinya adalah luhur dan universal, menekankan semangat kebersamaan dan persatuan, gotong royong, toleransi, kemanusiaan dan keadilan yang menjadi ciri khas karakter bangsa Indonesia. Adapun yang menjadikannya tidak bermakna karena nilai-nilai tersebut “dikangkangi” oleh manusia-manusia Indonesia sendiri.

Yudi Latif merumuskan secara apik pokok-pokok moralitas yang menjadi karakter bangsa Indonesia dalam Pancasila dapat dilukiskan sebagai berikut:

Pertama, nilai-nilai ketuhanan (religiositas) sebagai sumber etika dan spiritualitas (yang bersifat vertikal-transendental) dianggap penting sebagai fundamen etika kehidupan bernegara. Dalam kaitan ini, Indonesia bukanlah negara sekuler yang ekstrim, yang memisahkan "agama" dan "negara" dan berpretensi untuk menyudutkan peran agama ke ruang privat/komunitas. Negara menurut alam Pancasila bahkan diharapkan dapat melindungi dan mengembangkan kehidupan beragama; sementara agama diharapkan bisa memainkan peran publik yang berkaitan dengan penguatan etika sosial. Tetapi saat yang sama, Indonesia juga bukan "negara agama", yang hanya merepresentasikan salah satu (unsur) agama dan memungkinkan agama untuk mendikte negara. Sebagai negara yang dihuni oleh penduduk dengan multiagama dan multikeyakinan, negara Indonesia diharapkan dapat mengambil jarak yang sama terhadap semua agama/keyakinan, melindungi semua agama/keyakinan, dan harus dapat mengembangkan politiknya sendiri secara independen dari dikte-dikte agama.

Rasionalitas dari alam pemikiran Pancasila seperti itu mendapatkan pembenaran teoretik dan komparatifnya dalam teori-teori kontemporer tentang "public religion" yang menolak tesis "separation" dan "privatization", dan mendukung tesis "differentiation". Dalam teori ini, peran agama dan negara tidak perlu dipisahkan, melainkan dibedakan. Dengan syarat bahwa keduanya saling mengerti batas otoritas masing-masing, yang disebut dengan istilah "toleransi kembar" atau twin tolerations. 
Kedua, nilai-nilai kemanusiaan universal yang bersumber dari hukum Tuhan, hukum alam, dan sifat-sifat sosial manusia (yang bersifat horizontal) dianggap penting sebagai fundamen etika politik kehidupan bernegara dalam pergaulan dunia. Prinsip kebangsaan yang luas yang mengarah pada persaudaraan dunia itu dikembangkan melalui jalan eksternalisasi dan internalisasi. Keluar, bangsa Indonesia menggunakan segenap daya dan khazanah yang dimilikinya untuk secara bebas aktif "ikut melaksanakan ketertiban dunia yang berdasarkan kemerdekaan, perdamaian abadi dan keadilan sosial". Ke dalam, bangsa Indonesia mengakui dan memuliakan hak-hak dasar warga dan penduduk negeri. Landasan etik sebagai prasyarat persaudaraan universal ini adalah "adil" dan "beradab".

Komitmen bangsa Indonesia dalam memuliakan nlainilai kemanusiaan itu sangat visioner, mendahului "Universal Declaration of Human Rights” yang baru dideklarasikan pada 1948. Secara teoritik komparatif jalan eksternalisasi dan internalisasi dalam mengembangkan kemanusiaan secara adil dan beradab itu menempakan visi Indonesia dalam perpaduan antara perspektif teori "Idealisme politik" (political idealism) dan "realism politik" (political realism) yang berorientasi kepentingan nasional dalam hubungan internasional.

Ketiga, aktualisasi nilai-nilai etis kemanusiaan itu terlebih dahulu harus mengakar kuat dalam lingkungan pergaulan kebangsaan yang lebih dekat sebelum menjangkau pergaulan dunia yang lebih jauh. Dalam internalisasi nilai-nilai persaudaraan ini, Indonesia adalah negara persatuan kebangsaan yang mengatasi paham golongndan perseorangan. Persatuan dan kebhinekaan masyarakat Indonesia dikelola berdasarkan konsepsi kebangsaan yang mengekspresikan persatuan dalam keragaman, dan keragaman dalam persatuan, yang dalam slogan negara dinyatakan dengan ungkapan "Bhinneka Tunggal Ika". Di satu sisi, ada wawasan kosmopolitanisme yang berusaha mencari titik temu dari segala kebhinekaan yang terkristalisasikan dalam dasar negara (Pancasila), UUD, dan segala turunan perundang-undangannya, negara persatuan, bahasa persatuan, dan simbol-simbol kenegaraan lainnya. Di sisin lain, ada wawasan pluralisme yang menerima dan 
memberi ruang hidup bagi aneka perbedaan, seperti aneka agama/ keyakinan, budaya dan bahasa daerah, dan unit-unit politik tertentu sebagai warisan tradisi budaya.

Dengan demikian, Indonesia memiliki prinsip dan visi kebangsaan yang kuat, yang bukan saja dapat mempertemukan kemajemukan masyarakat dalam kebaruan komunitas politik bersama, tetapi juga mampu memberi kemungkinan bagi keragaman komunitas untuk tidak tercerabut dari akar tradisi dan kesejarahannya masing-masing. Dalan khazanah teori tentang kebangsaan, konsepsi kebangsaan Indonesia menyerupai perspektif "etnosimbolis", yang memadukan antara perspektif "modernis" yang menekankan unsur-unsur kebaruan dalam kebangsaan, dengan perspektif "primordialis" dan "perenialis" yang melihat keberlangsungan unsur-unsur lama dan kebangsaan.

Keempat, nilai ketuhanan, nilai kemanusiaan, dan nilai serta cita-cita kebangsaan itu dalam aktualisasinya harus menjunjung tinggi kedaulatan rakyat dalam semangat permusyawaratan yang dipimpin oleh hikmat kebijaksanaan. Dalam visi demokrasi permusyawaratan, demokrasi memperoleh kesejatiannya dalam penguatan daulat rakyat, ketika kebebasan berpolitik berkelindan dengan kesetaraan ekonomi, yang menghidupkan semangat persaudaraan dalam kerangka "musyawarah mufakat". Dalam prinsip musyawarah mufakat, keputusan tidak didekte oleh golongan mayoritas (mayorokrasi) atau kekuatan minoritas elite politik dan penguasa (minorokrasi), melainkan dipimpin oleh hikmat/kebijaksanaan yang memuliakan daya-daya rasionalitas deliberative dan kearifan setiap warga tanpa pandang bulu.

Kelima, nilai ketuhanan, nilai kemanusiaan dan cinta kebangsaan, serta demokrasi permusyawaratan itu memperoleh kepenuhan artinya sejauh dapat mewujudkan keadilan sosial.Di satu sisi, perwujudan keadilan sosial itu harus mencerminkan imperatif etis keempat sila lainnya. Di sisi lain, otentisitas pengalaman silasila Pancasila bisa ditakar dari perwujudan keadilan sosial dalam perikehidupan kebangsaan. Dalam visi keadilan sosial menurut Pancasila,yangdikehendakiadalahkeseimbangan antarapemenuhan kebutuhan jasmani dan rohani, keseimbangan antara peran manusia sebagai makhluk individu (yang terlembaga dalam pasar) dan peran 
manusia sebagai makhluk sosial (yang terlembaga dalam negara), juga keseimbangan antara pemenuhan hak sipil dan politik dengan hak ekonomi, sosial, dan budaya. Dalam suasana kehidupan sosial perekonomian yang ditandai oleh aneka kesenjangan sosial, kompetisi ekonomi diletakkan dalam kompetisi yang kooperatif berlandaskan asas kekeluargaan; cabang-cabang produksi yang penting bagi negara dan yang menguasai hajat hidup orang banyak dikuasai oleh negara; bumi, air dan kekayaan alam yang terkandung didalmnya dikuasai oleh negara dan dipergunakan sebesar-besarnya untuk kemakmuaran rakyat. Dalam mewujudkan keadilan sosial, masing-masing pelaku ekonomi diberi peran masing-masing yang secara keseluruhan mengembangkan semangat kekeluargaan. Peran individu (pasar) diberdayakan, dengan tetap menempatkan Negara dalam posisi yang penting dalam menyediakan kerangka hukum dan regulasi, fasilitas, penyediaan, dan rekayasan sosial, serta penyediaan jaminaan sosial.

Demikianlah, para pendiri bangsa ini telah mewariskan kepada kita suatu dasar falsafah dan pandangan hidup negara - yang menjiwai penyusunan UUD - yang begitu visioner dan tahan banting (durable). Suatu dasar falsafah yang memiliki landasan ontologis, epistemologis, dan aksiologis yang kuat, yang jika dipahami secara mendalam, diyakini secara teguh, dan diamalkan secara konsisten dapat mendekati perwujudan "Negara Paripurna" ${ }^{31}$

Nilai-nilai luhur dan universal yang menjadi pilar bangsa tersebut tentunya tidak hanya berada pada tataran urutan-urutan verbal semata, tetapi hendaknya dioperasionalisasikan secara konsisten di segala lapis dan bidang kehidupan berbangsa dan bernegara. Agar Pancasila tetap eksis dan tetap menjadi acuan, maka strategi utama adalah melakukan revitalisasi epistemologis, yaitu Pancasila harus dikembangkan melalui suatu kajian ilmiah di dunia pendidikan di Indonesia. Revitalisasi nilai-nilai Pancasila melalui proses epistemologis tersebut akan sekaligus mempertahankan nilai-nilai budaya bangsa sebagai suatu identitas bangsa dan negara Indonesia. ${ }^{32}$ Oleh karena itu sangat mengherankan jika semenjak

${ }^{31}$ Latif, Negara Paripurna....., h. 42-47.

${ }^{32}$ Kaelan, "Revitalisasi dan Reaktualisasi Pancasila Sebagai Dasar Filsafat dan Ideologi Bangsa dan Negara Indonesia”, dalam Mintaredja dkk. (ed.), Memaknai Kembali...., h. 13. 
era reformasi banyak perguruan tinggi yang tidak lagi menyajikan mata kuliah Pancasila dan menggantikannya dengan mata kuliah pendidikan kewargaan. Padahal substansi dari kedua mata kuliah tersebut terdapat perbedaan.

Staf Ahli Kementerian Politik, Hukum dan HAM (Kempolhukam) Cristina M. Rantetana mengatakan banyak mahasiswa saat ini kesulitan memahami Pancasila, UUD 1945, Bhinneka Tunggal Ika dan NKRI. Kondisi ini menjadi ancaman besar bagi kemajemukan bangsa. Ia mencontohkan sejumlah mahasiswa yang berbeda fakultas atau kampus sering terlibat bentrokan atau tawuran hanya diakibatkan persoalan sepele. Selain itu, lanjutnya, kondisi faktual ini juga membawa degradasi moral dan akhlak dengan dalih norma agama, menguatnya semangat kedaerahan, serta dampak negatif globalisasi. Hal ini terjadi karena pada saat reformasi 1998 meletus, segala nilaiyang tertanam di era sebelumnya dianggap buruk sehingga semuanya ditinggalkan. Sementara itu, nilai-nilai baru sampai sekarang belum muncul. "Saat ini, nilainilai yang lalu semuanya dianggap jelek, sedangkan nilai-nilai yang baru belum juga ditemukan, akhirnya negara menjadi tak karukaruan".33

Melihat fenomena tersebut, pemerintah melalui Menteri Pendidikan Nasional telah mencanangkan bahwa Pendidikan Pancasila harus dikembalikan dalam kurikulum pendidikan. Mendiknas usai membuka acara System Assesment and Benchmarking for Educations Results (SABER) di Nusa Dua Bali tanggal 5 Juni 2011 yang lalu menyatakan, Pendidikan Pancasila akan dimasukkan kembali dalam kurikulum pendidikan sekolah. Sebagaimana diketahui bahwa Pendidikan Pancasila dan Kewarganegaraan (PPKn) diubah menjadi Pendidikan Kewarganegaraan (PKn) sesuai amanat UndangUndang Sisdiknas tahun 2003.

Kontekstualisasi dan implementasi nilai-nilai keempat pilar bangsa melalui dunia pendidikan ini adalah yang paling strategis, karena pendidikan tidak hanya mencetak manusia-manusia yang cerdas, trampil namun juga mempertahankan, mengembangkan dan mengaktualisasikan nilai-nilai filosofi bangsa sebagai local genius sekaligus sebagai ciri khas dan identitas bangsa.

${ }^{33}$ Lampung Post, “Pemahaman Pancasila Krisis”, 30 Mei 2011. 
Selain itu, menurut Moh. Mahfud MD, langkah strategis yang dapat dilakukan adalah mengarus utamakan wacana publik tentang pilar bangsa sehingga hidup dan berkembang. Dalam proses diskusi publik, kedudukan dan nilai-nilai pilar bangsa dielaborasi dan akan menemukan kristalisasi obyektif tanpa adanya pemaksaan dan hegemoni. Langkah ini juga menghindari munculnya tafsir tunggal yang dipaksakan oleh kekuasaan negara seperti yang kita alami pada masa lalu. ${ }^{34}$

Meskipun begitu, uraian diatas tidaklah samasekalimembuat dan menganggap pilar bangsa sebagai suatu yang sempurna dan untouchable. Sebab sebagai hasil dari pikiran mendalam manusia yang tentu saja kemungkinan masukan-masukan sesuai dengan perkembangan zaman amatlah diperlukan. Dengan begitu kita bukan hanya mengembalikan "citra pilar bangsa", tapi juga membuktikan pentingnya keempat pilar bangsa tersebut bagi kehidupan berbangsa dan bernegara saat ini maupun di masa yang akan datang.

Karena itu, tidak ada alasan bagi masyarakat Indonesia pada umumnya untuk tidak menerima keempat pilar bangsa sebagai dasar negara, landasan hukum, dan landasan persatuan dan menjadikannya karakter bangsa Indonesia. Hal ini disebabkan karena nilai-nilai pilar bangsa sangat bersesuaian dengan spirit dan ajaran dari agama-agama yang ada, seperti kemanusiaan, persatuan, kerakyatan, permusyawaratan.

\section{G. Penutup}

Sebagai pewaris perjuangan bangsa, maka manusia Indo-

${ }^{34}$ Moh. Mahfud MD, "Ceramah Kunci Ketua Mahkamah Konstitusi Pada Kongres Pancasila di Yogyakarta 30 Mei 2009”, dalam Agus Wahyudi dkk.(ed.), Proceeding Kongres Pancasila ; Pancasila dalam Berbagai Perspektif, (Yogyakarta: Pusatu Studi Pancasila UGM, 2009), h. 11. Damardjati Supadjar pernah mengusulkan untuk mengefektifkan Pancasila, caranya ialah menjadikan perumusan sila-sila yang berupa kata benda abstrak sebagai kata kerja aktif. Jadi, bukan saja Ketuhanan Yang Maha Esa, tapi "Mengesakan Tuhan”. Bukan hanya kemanusiaan yang adil dan beradab, tapi "Membangun kemanusiaan yang adil dan beradab". Bukan saja Persatuan Indonesia, "Mempersatukan Indonesia”. Bukan saja kerakyatan, tapi "Melaksanakan Kerakyatan”. Bukan hanya Keadilan Sosial, tapi "Mengusahakan Keadilan Sosial”. Lihat Latif, Negara Paripurna..... (catatan kaki no. 46), h. 47. 
nesia saat ini seharusnya dapat menghargai apayang telah ditetapkan dan disepakati oleh founding fathers Negara bangsa Indonesia yaitu Pancasila, UUD 1945, Bhinneka Tunggal Ika dan Negara Kesatuan Republik Indonesia sebagai sesuatu yang harus dijunjung tinggi oleh semua elemen bangsa dengan cara memahami esensinya lalu diimplentasikan secara konkrit dalam kehidupan empirik supaya kompatibilitas dan kebernasannya dapat dirasakan. Selain itu, menjadi kewajiban kita semua untuk mengamankan keempat pilar bangsa tersebut dari adanya keinginan-keinginan kelompok tertentu untuk menafikannya, agar supaya masa depan bangsa Indonesia akan tetap berada dalam situasi yang kondusif. []

\section{Daftar Pustaka}

Anshari, Endang Syaifuddin. 2001, Piagam Jakarta 22 Juni 1945; Sebuah Konsensus Tentang Dasar Negara Republik Indonesia (1945-1949), Bandung: Gema Insani Press, 2009.

Ali, As'ad Said, Negara Pancasila Jalan Kemaslahatan Berbangsa, Jakarta: LP3ES.

Bahar, Saafroedin, dkk, Risalah Sidang Badan Penyelidik Usaha-Usaha Persiapan Kemerdekaan Indonesia (BPUPKI) - Panitia Persiapan Kemerdekaan Indonesia (PPKI) : 28 Mei 1945 - 22 Agustus 1945, Jakarta: Sekretariat Negara Republik Indonesia, 1995.

Bentara Kompas, No. 9. Tahun I, Jum'at, 6 Oktober, 2000.

Departemen Pendidikan dan Kebudayaan, Kamus Besar Bahasa Indonesia, Jakarta: Balai Pustaka, 1989.

Gibbons, Michael T. , Interpreting Politics, New York : New York University Press, 1987.

Hadi, P. Hardono, Hakikat dan Muatan Filsafat Pancasila, Yogyakarta: Kanisius, 1994.

Hidayat, Komaruddin, Wahyu di Langit Wahyu di Bumi; Doktrin dan Peradaban Islam di Panggung Sejarah, Jakarta: Paramadina, 2003.

Husaini, Adian, Pancasila Bukan Untuk Menindas Hak Konstitusional Umat Islam, Jakarta : Gema Insani Press, 2009. Mintaredja, 
Abbas Hamami, dkk. (ed.), Memaknai Kembali Pancasila, (Yogyakarta: Badan Penerbit Filsafat UGM, 2007.

Irfan Nasution dan Roni Agustinus (Peny.), Restorasi Pancasila; Mendamaikan Politik Identitas dan Modernitas, Jakarta: FISIP UI, 2006.

Ismail, Faisal, Pilar-pilar Islam; Pergumulan Kultur dan Struktur, Yogyakarta: LESFI, 2002.

Kamil, Syukron, "Fenomena Gerakan Penerapan Syari'at Islam: Studi Atas Majelis Mujahidin Indonesia' dalam Dialog: Jurnal Penelitian dan Kajian Keagamaan, No. 59 Th. XXVIII, Juni 2005.

Kurniawan, Abdullah, "Fenomena Gerakan Politik Ekstra Parlementer: Studi atas Hizbut Tahrir Indonesia' dalam Dialog: Jurnal Penelitian dan Kajian Keagamaan, No. 59 Th. XXVIII, Juni 2005.

Kompas, Presiden: "Pertahankan Pancasila Habis-Habisan”, 2 Juni 2000.

Lampung Post, "Pelajaran Pancasila Kembali Masuk Kurikulum”, 6 Juni 2011.

Lampung Post, "Pemahaman Pancasila Krisis", 30 Mei 2011.

Latif, Yudi, Negara Paripurna; Historisitas, Rasionalitas dan Aktualitas Pancasila, Jakarta : Gramedia Pustaka Utama, 2001.

Ma'arif, Ahmad Syafi'i, Islam dan Masalah Kenegaraan; Studi Tentang Percaturan dalam Konstituante, Jakarta: LP3ES, 1985.

Madjid, Nurcholish, Islam Agama Kemanusiaan; Membangun Tradisi dan Visi Baru Islam Indonesia, Jakarta: Paramadina, 1995.

Mas'udi, Masdar Farid, Syarah Konstitusi UUD 1945 Dalam Perspektif Islam, Jakarta: Alvabet, 2010.

Nasution, Adnan Buyung, The Aspiration for Constitutional Government in Indonesia : A Socio-Legal Study of the Indonesian Konstituante 1956-1959, Jakarta : Pustaka Sinar Harapan, 1992.

Rozak, Abdul dkk. (ed.), Pendidikan Kewargaan: Demokrasi, Hak Asasi Manusia, dan Masyarakat Madani, Jakarta: Tim ICCE UIN Jakarta, 2000.

Smith, Donald Eugene, Agama ditengah Sekulerisasi Politik, terj. Azyumardi Azra, Jakarta : Pustaka Panjimas, 1985.

Soejadi, Pancasila Sebagai Sumber Tertib Hukum Indonesia, Yogyakarta: Lukma Offset, 1999. 
Stokhof, W.A.L. dan Djamal, Murni (redaktur), Konflik Komunal di Indonesia Saat ini, Jakarta - Leiden: INIS dan Pusat Bahasa UIN Syarif Hidayatullah, 2003.

Sukardja, Ahmad, Piagam Madinah dan Undang-Undang Dasar 1945; Kajian Perbandingan Tentang Dasar Hidup Bersama Dalam Masyarakat yang Majemuk, Jakarta: UI Press, 1995.

Titaley, John A. , Nilai-Nilai Dasar yang Terkandung Dalam Pembukaan Undang-Undang Dasar 1945, Salatiga: Fakultas Teologi Universitas Kristen Satya Wacana, 1999.

Wahid, Marzuki dan Rumadi, Fiqh Mazhab Negara; Kritik atas Politik Hukum Indonesia, Yogyakarta : Lkis, 2001.

Wahyudi, Agus, dkk.(ed.), Proceeding Kongres Pancasila; Pancasila dalam Berbagai Perspektif, Yogyakarta : Pusat Studi Pancasila UGM, 2009.

Zein, Kurniawan dan H.A, Sarifuddin (ed.), Syariat Islam Yes Syariat Islam No; Dilema Piagam Jakarta dalam Amandemen UUD 1945, Jakarta: Paramadina, 2001. 
